\title{
Hydrothermal treatment minimizes the effects of refrigeration in okra fruits
}

\author{
Fernanda Cristina S Ribeiro' ${ }^{1}$; Tania P Silva ${ }^{2}$; Ludmila LM Neves ${ }^{1}$; Fernando Luiz Finger ${ }^{1}$ \\ ${ }^{1}$ Universidade Federal de Viçosa (UFV), Viçosa-MG, Brasil; fernandacristina_ufv@yahoo.com.br; ffinger@ufv.br; 1lafeta@yahoo.com.br; \\ ${ }^{2}$ Universidade Federal dos Vales do Jequitinhonha e Mucuri (UFVJM), Unaí-MG, Brasil; taniapiresdasilva@yahoo.com.br
}

\begin{abstract}
This study evaluated the involvement of peroxidase and polyphenoloxidase on the enzymatic browning of okra and the role of catalase in the appearance of chilling injury in cultivars Amarelinho and Mammoth Spineless treated with hot water. Okra fruits from two cultivars were immersed in water at $40^{\circ} \mathrm{C}$, during 15 and 30 minutes. The control treatment was not immersed, and all fruits were stored at $5^{\circ} \mathrm{C}$. Visual analysis of fruits was carried out and total chlorophyll content and total phenolic compounds were determined. The activity of the enzymes catalase, peroxidase and polyphenoloxidase was analyzed. In all treatments, the cultivar Mammoth Spineless showed higher values of chlorophyll content and soluble phenolic compounds compared to cultivar Amarelinho. For both cultivars, catalase activity was higher at the last days of storage, regardless if the fruits were immersed or not in hot water. However, the catalase activity was higher in 'Mammoth Spineless', which presented the higher tolerance to chilling injury. The fruit skin browning was coincident with the increase on polyphenoloxidase activity and phenolic compounds content. This relationship was not observed for the peroxidase activity. The heat treatment during 15 minutes increased the length of storage of cultivar Amarelinho, and for 30 minutes of the cultivar Mammoth Spineless.
\end{abstract}

Keywords: Abelmoschus esculentus, catalase, peroxidase, polyphenoloxidase, heat treatment.

\section{RESUMO}

Tratamento hidrotérmico minimiza os efeitos da refrigeração em frutos de quiabo

O objetivo desse trabalho foi avaliar a relação das enzimas peroxidase e polifenoloxidase com o escurecimento enzimático do quiabo e analisar o envolvimento da catalase com o aparecimento de injúria por frio, em frutos das cultivares Amarelinho e Mammoth Spineless imersos em água quente. Frutos de quiabo das duas cultivares foram imersos em água a $40^{\circ} \mathrm{C}$ por 15 e 30 minutos. $\mathrm{O}$ tratamento controle não foi imerso, e todos os frutos foram armazenados a $5^{\circ} \mathrm{C}$. Realizou-se a análise visual dos frutos e determinou-se os teores de clorofilas totais e compostos fenólicos totais. Analisou-se a atividade da enzima catalase, peroxidase e polifenoloxidase. Em todos os tratamentos, a cultivar Mammoth Spineless apresentou valores de clorofila e compostos fenólicos superiores em relação à cultivar Amarelinho. A catalase apresentou maior atividade, para as duas cultivares, nos últimos dias de armazenamento, para frutos imersos ou não. Porém, a atividade da catalase foi maior em 'Mammoth Spineless' que foi a que apresentou maior tolerância à injúria chilling. O escurecimento dos frutos coincidiu com o aumento da atividade da enzima PPO e do conteúdo de compostos fenólicos. Para a peroxidase, esta relação, não foi observada. $O$ tratamento térmico durante 15 e 30 minutos proporcionou maior período de conservação para as cultivares Amarelinho e Mammoth Spineless, respectivamente.

Palavras-chave: Abelmoschus esculentus, catalase, peroxidase, polifenoloxidase, tratamento térmico.

\section{Received on November 7, 2016; accepted on April 3, 2017}

$\mathrm{O}$ kra is originally from Africa and was brought to Brazil by the slaves. Cultivated mainly in the Northeast and Southeast regions, okra finds in Brazil excellent growing conditions (Mota et al., 2000). However, the period of postharvest shelf life is short, mainly under room temperature and low relative humidity, which leads to accelerated loss of water, depreciating commercial value of fruit for fresh consumption (Finger et al., 2008).

Temperature of storage is the most important environmental factor to extend the shelf life of fresh fruits and vegetables. However, products of tropical and subtropical origin can be seriously damaged during cold storage, usually under temperatures between 5 and $13{ }^{\circ} \mathrm{C}$. Sevillano et al. (2009) show that the development of chilling is triggered by low temperatures, but above freezing point. Chilling injury symptoms in okra fruits appear as points of depression on the surface associated with a further browning under temperature of $5^{\circ} \mathrm{C}$ (Finger et al., 2008). This limits the storage of tropical and subtropical fruits and vegetables due to their sensitiveness to cold stress. The susceptibility to low temperatures of this particular set of cold-sensitive horticultural products causes the appearance of physiological disorders (the whole set is known as CI), which have detrimental effects on their quality (Aghdam et al., 2013).

Phenolic compounds have important role on determining flavor and color of fruits and vegetables and those are involved on enzymatic browning reactions due to injuries. Browning is related to enzyme activity by the oxidation of the phenolic compounds catalyzed by the polyphenoloxidase (Menolli et al., 2008; Pasquariello et al., 2015) and peroxidase (Silva et al., 2009). These biochemical changes occur 
during the cold storage process and can produce significant loss of quality.

One technique that has been used to avoid the development of chilling injury is the manipulation of temperature before storage at low temperature. The thermal pre-treatment with immersion in hot water significantly reduced the symptoms of chilling injury in loquat (Edagi et al., 2009) and bananas (Wang et al., 2012), without changing other fruit characteristics and helped to delay the ripening of cucumbers (Zhanga et al., 2014).

According to Aghdam et al. (2013), fruit ripening, low temperature and oxidative stress induce the synthesis of heat shock proteins. These conditions are involved in chilling injury development in sensitive fruits and vegetables. The heat shock proteins can also play a protective role against the secondary oxidative stress occurring in most of the stressful conditions suffered by the plant, as low temperatures. In plants, the protection against oxidative stress, is by a complex antioxidant system that includes antioxidant enzymes and antioxidant metabolites.

A previous work has also shown the ability of a heat treatment to promote the accumulation of heat shock proteins in plants, in response to high temperatures (Son et al., 2012, Wu et al., 2015).

However, the physiological base for tolerance by using immersion in hot water before storage at low temperatures is not fully understood in okra, in relation to the activity of enzymes.

In this context, the study evaluated the involvement of peroxidase and polyphenoloxidase on the enzymatic browning of okra and the role of catalase in the appearance of chilling injury in two cultivars treated with hot water.

\section{MATERIAL AND METHODS}

Fruits of okra cultivars Amarelinho and Mammoth Spineless, grown on the garden of the Universidade Federal de Viçosa (UFV), were harvested between the sixth and the eighth day after anthesis, with 8 to $13 \mathrm{~cm}$ in length, from
December to April. Soil preparation and cultural practices were performed according to the recommendations for the crop (Correia et al., 1999).

Fruits were immersed in hot water at $40^{\circ} \mathrm{C}$ during 15 and 30 minutes, and the control treatment remained without immersion. After immersion, the fruits were dried with a paper towel and placed in polystyrene trays $(15 \times 20 \mathrm{~cm})$ covered with a layer of PVC film (polyvinyl chloride). Then the trays were stored at $5^{\circ} \mathrm{C}$ and relative humidity of $90 \pm 2 \%$ for 16 days. Treatments were arranged in a $2 \times 3$ factorial arrangement, with 2 cultivars and 3 times of immersion in water, in a randomized block design with 4 replications. Each plot consisted of a tray on which were placed 15 fruits.

Development of chilling injury was scored at every two days according to a grading scale described by Finger $e t$ al. (2008).

The severity of injuries was assessed according to shelf life condition, by using a scale of subjective grading varying from 0 to 4 : (0) absence of any point of injury depression on the fruit surface, (1) less than 5 points, (2) 5 to 10 points of injury, (3) 11 to 15 points of injury and (4) more than 15 points of chilling injury.

The presence of dark spots on the fruit was assessed receiving score from 0 to 4: (0) no browning (1) small spots, (2) larger spots in approximately $30 \%$ of the fruit, (3) spots occupying between 30 to $50 \%$ the surface of the fruit and (4) spots occupying more than $50 \%$ of the fruit surface.

The total chlorophyll content was determined by the method of Arnon (1949), using a spectrophotometer at 645 and $663 \mathrm{~nm}$.

The determination of catalase activity was performed according to the method of Kar \& Mishra (1976) with modifications. Approximately $2 \mathrm{~g}$ of the external pericarp was homogenized in $10 \mathrm{~mL}$ of $0.1 \mathrm{M}$ phosphate buffer, $\mathrm{pH}$ 7.0 and the resulting suspension passed through four layers of cheese cloth and centrifuged at $17.000 \mathrm{~g}$ at $4^{\circ} \mathrm{C}$ during 30 minutes. An aliquot of the supernatant was removed and mixed with $0.11 \mathrm{~mL}$ of $0.1 \mathrm{mM} \mathrm{H}_{2} \mathrm{O}_{2}$ and $2.5 \mathrm{~mL}$ of $0.1 \mathrm{M}$ phosphate buffer, $\mathrm{pH}$ 7.0. The reaction mixture was incubated in water bath at $25^{\circ} \mathrm{C}$ during one minute and the reaction was stopped by adding $10 \mathrm{~mL}$ of $2 \% \mathrm{H}_{2} \mathrm{SO}_{4}(\mathrm{v} / \mathrm{v})$. The residual $\mathrm{H}_{2} \mathrm{O}_{2}$ was titrated with $0.01 \mathrm{~N} \mathrm{KMnO}_{4}$ until a light purple color persists for at least 15 seconds. A control sample was prepared in the same way, but the enzyme activity was stopped at "time zero" of reaction. The activity was expressed in $\mu$ moles of $\mathrm{H}_{2} \mathrm{O}_{2}$ consumed/min/mg protein.

To determine the polyphenoloxidase activity, approximately $2 \mathrm{~g}$ of the external pericarp of each sample was homogenized with $10 \mathrm{~mL}$ extraction buffer $(0.1 \mathrm{M}$ phosphate buffer, $\mathrm{pH}$ $6.8,0.5 \%$ Triton $\mathrm{X}-100$ and $10 \mathrm{mM}$ ascorbic acid). The resulting suspension was centrifuged at $4{ }^{\circ} \mathrm{C}$ and 17.000 $g$ during 30 minutes, according to Concellón et al. (2004). An aliquot of the supernatant was taken, mixed with $0.5 \mathrm{~mL}$ of distilled water, $0.5 \mathrm{~mL}(0.12$ M) 4-methyl catechol and $1.5 \mathrm{~mL}(0.1$ M) citric acid, $\mathrm{pH}$ 5.0. The reaction was determined in spectrophotometer by the changes in absorbance at $395 \mathrm{~nm}$, during 3 minutes. Enzyme activity was expressed as absorbance units (AU)/ $\mathrm{min} / \mathrm{mg}$ protein.

For the determination of the peroxidase activity approximately $2 \mathrm{~g}$ of sample from the external pericarp homogenized in $10 \mathrm{~mL}$ extraction buffer containing phosphate buffer $(0.1 \mathrm{M})$ $\mathrm{pH} 6.5,0.1 \%$ sodium bisulphite and sodium chloride $(0.15 \mathrm{M})$ (Lagrimini et al., 1997). The resulting suspension was centrifuged at $17.000 \mathrm{~g}, 4^{\circ} \mathrm{C}$ during 30 minutes. A $0.2 \mathrm{~mL}$ aliquot from the supernatant was mixed with $1.3 \mathrm{~mL}$ of $0.56 \%$ guaiacol, $1.5 \mathrm{~mL}$ of phosphate buffer $(0.2 \mathrm{M}) \mathrm{pH} 6.5$ and $2 \% \mathrm{H}_{2} \mathrm{O}_{2}$. The reactions were determined in a spectrophotometer by the changes in absorbance at $470 \mathrm{~nm}$ during 3 minutes. Peroxidase activity (POD) expressed in AU/min/mg protein.

The total amount of protein in the extracts was determined as described by Bradford (1976) using Bovine Serum Albumin as standard.

The determination of total phenolic compounds was performed according to the method described by Kubota (1995). The readings were performed in spectrophotometer at $700 \mathrm{~nm}$ and 
the results were expressed in $\mu \mathrm{g}$ of soluble phenols per $g$ of fresh weight. A calibration curve with D-catechin was used as standard.

Data were analyzed using the software SAEG and submitted to analysis of variance and regression $(p<0.1)$. The results of the visual analysis of the fruits were evaluated using descriptive statistics.

\section{RESULTS AND DISCUSSION}

Time of storage influenced the development of symptoms of chilling

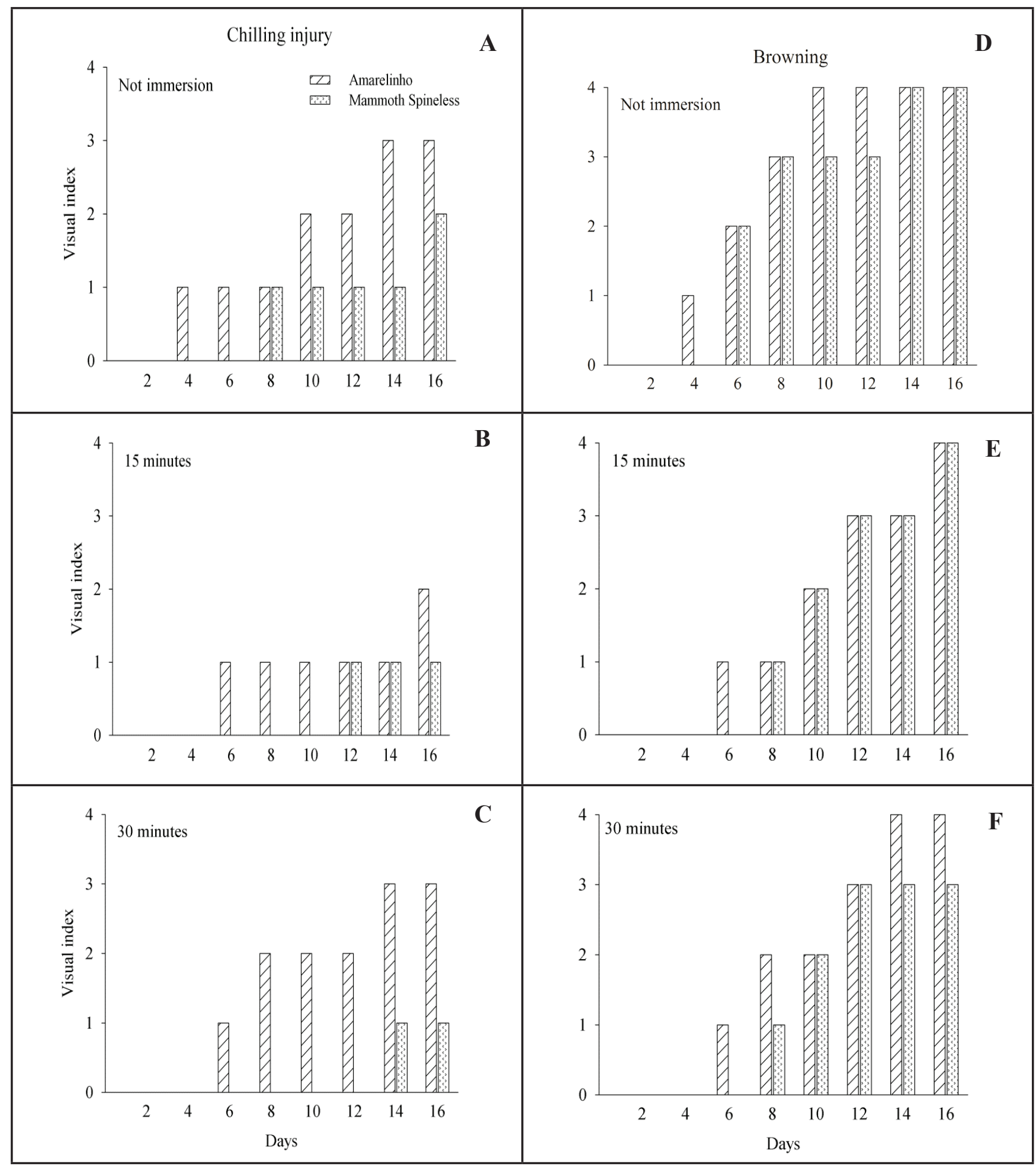

Figure 1. Values of visual scales to chilling injury and browning in okra cultivars Amarelinho and Mammoth Spineless without immersion (A and D) and immersed during $15(\mathrm{~B}$ and $\mathrm{E})$ and $30(\mathrm{C}$ and $\mathrm{F})$ minutes in water at $40^{\circ} \mathrm{C}$ and stored during $2,4,6,8,10,12,14$ and 16 days at $5^{\circ} \mathrm{C}$. Viçosa, UFV, 2014. 
injury in both cultivars. However, fruits from cultivar Mammoth Spineless were more tolerant than the cultivar Amarelinho when stored at $5^{\circ} \mathrm{C}$ (Figure $1)$. The fruits control from cultivar Amarelinho began to develop brown spots and early symptoms of injury on day 4 (Figure 1a), while the heat treated fruits developed similar symptoms after 6 days of storage (Figures. 1b and 1c). By the $8^{\text {th }}$ day of storage, control fruits showed $30-50 \%$ of darkened surface (Figure 1a), while the hot water treated fruits browning occurred on the $12^{\text {th }}$ day of storage (Figures $1 \mathrm{~b}$ and 1c). After 14 days of storage, only the fruits treated during 15 minutes with hot water did not reach stage 3 of chilling injury (Figure 1b). Thus, the heat treatment during 15 minutes was a suitable treatment to increase the length of storage on cultivar Amarelinho.

The control fruits from cultivar Mammoth Spineless began browning on the $6^{\text {th }}$ day of storage (Figure 1d) and by the $8^{\text {th }}$ day presented $30-50 \%$ damage (Figure 1e). Fruits treated with water at $40^{\circ} \mathrm{C}$ by immersion began to show browning symptoms on the $8^{\text {th }}$ day and became severe only at the $12^{\text {th }}$ day (Figures 1e and 1f). Symptoms of chilling injury, in this cultivar started in control fruits, followed by those treated during 15 minutes and immersed for 30 minutes at $8^{\text {th }}, 12^{\text {th }}$ and $14^{\text {th }}$ day of storage, respectively (Figures 1a, 1b and 1c). The heat treatment during 30 minutes retained fruit quality, extended storage life and increased the length of storage of the cultivar. However, none of the treatments presented more than 10 points of chilling injury (stage 3 ), demonstrating greater resistance of this cultivar to chilling. Treatment with hot water influenced positively the storage of okra, delaying the symptoms of chilling.

Shadmani et al. (2015) reported that there was a significant difference in the chilling development between hot water dipped and control fruit stored at $6^{\circ} \mathrm{C}$, and it could be concluded that the application of hot water as a pre-conditioning treatment induced tolerance to chilling. Hot water treatment stimulates the defense mechanisms, before the fruits are subjected to cold, which establish cross-resistance to lower temperatures (Yimyong et al., 2011).

Browning and necrosis were present in fruits of both cultivars when stored at $5^{\circ} \mathrm{C}$. Mota et al. (2010) determined that the incidence of injury and browning in fruits stored at $5^{\circ} \mathrm{C}$ with PVC, appeared three days after harvest, but good state of preservation remained until the $6^{\text {th }}$ day.

The levels of total chlorophyll in fruits of 'Amarelinho' showed quadratic behavior with the increasing immersion time in hot water and day of sampling. The highest levels in the total chlorophyll were found when immersed in water during 11.02 minutes at $40^{\circ} \mathrm{C}$ at the beginning of storage $(70.1 \mathrm{~g} / \mathrm{g}$ FW) (Figure 2a). For fruits of cultivar Mammoth Spineless, the levels of total chlorophyll varied linearly with the length of treatment and day of sampling (Figure 2b).

The amount of chlorophyll on 'Mammoth Spineless' reduced during storage, as occurred with the fruits of cultivar Amarelinho, but the longer the time of water treatment, the higher the level of remaining chlorophyll during storage.

Fruits of cultivar Mammoth Spineless showed higher content of chlorophyll than Amarelinho for all treatments and sampling days. This result was expected because fruits of cultivar Mammoth Spineless are deeper green than fruits from cultivar Amarelinho, which are more yellow, as its name suggests.

When comparing the behavior of the two cultivars regarding to catalase activity, no differences in general were observed (Figure 3). For both cultivars, catalase activity was higher at the last days of storage regardless if the fruits were immersed or not in hot water. However, the catalase activity was higher in 'Mammoth Spineless' which presented the higher tolerance to chilling injury. These results demonstrated that catalase activity (CAT) may act in

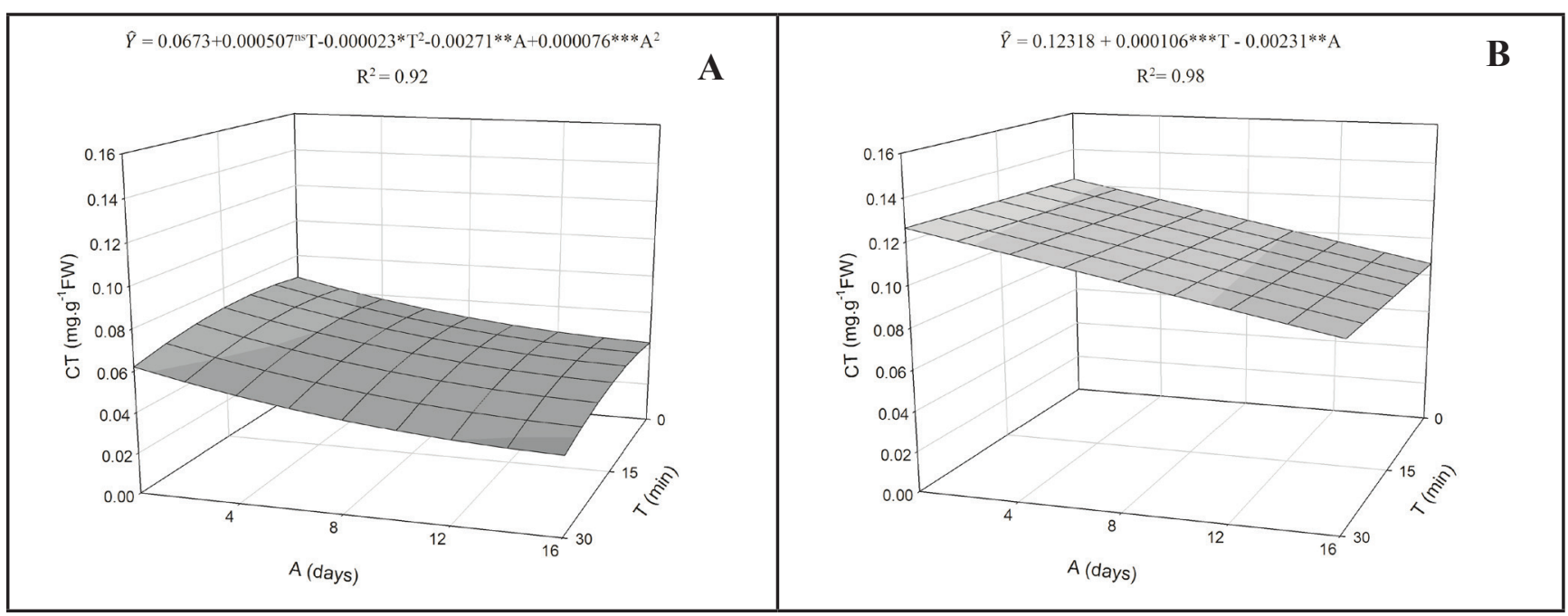

Figure 2. Estimation of total chlorophyll content $(\mathrm{CT})(\mathrm{mg} / \mathrm{g} \mathrm{FW})$ in okra cultivars Amarelinho (A) and Mammoth Spineless (B) stored at $5^{\circ} \mathrm{C}$, depending on time of immersion (T) in water at $40^{\circ} \mathrm{C}$ (not immersed, 15 and 30 minutes immersed) and the sampling days $(\mathrm{A})(0,4$, 8, 12 and 16 days). Viçosa, UFV, 2014. 


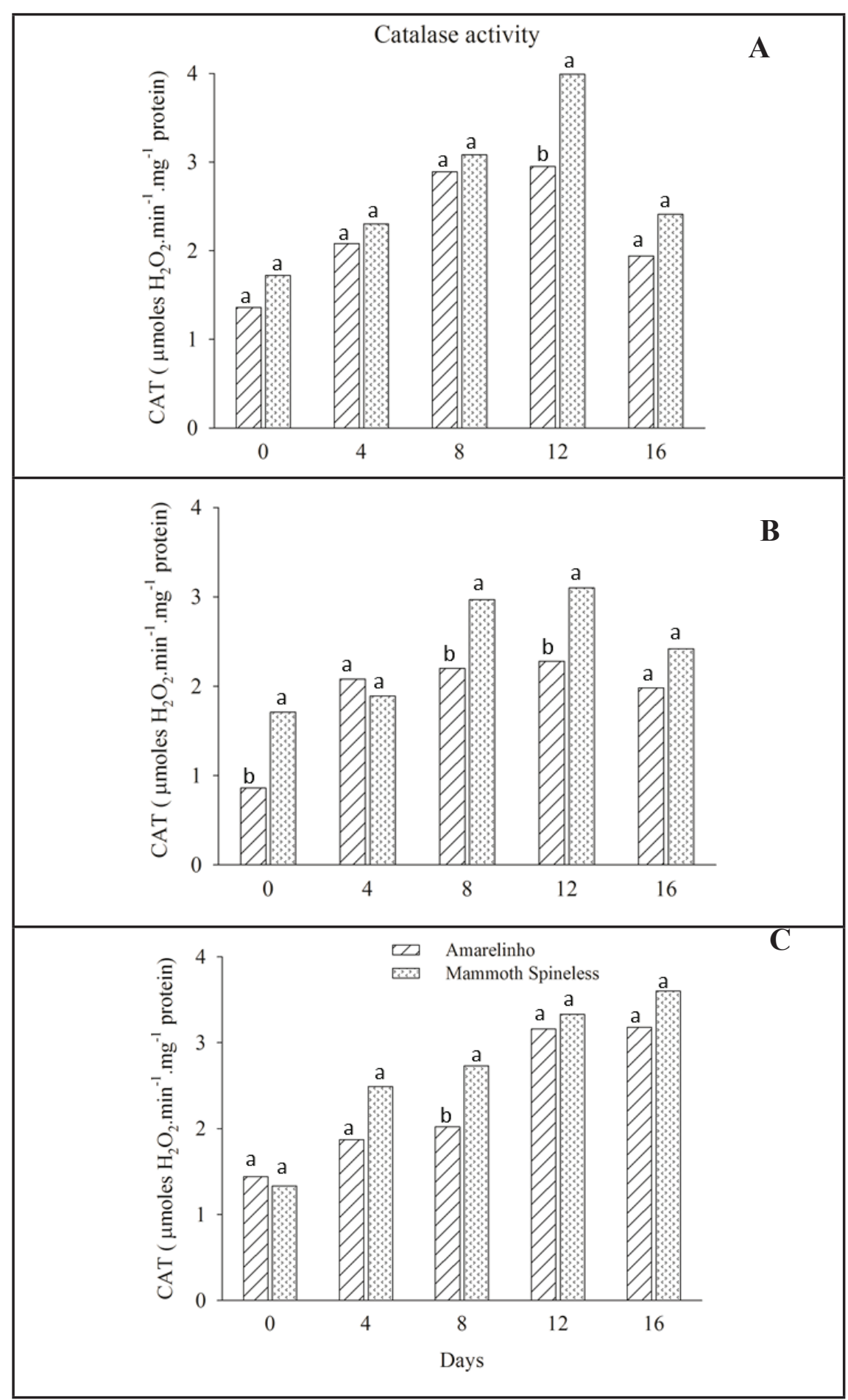

Figure 3. Mean values of catalase activity (CAT) ( $\mu$ moles of $\mathrm{H}_{2} \mathrm{O}_{2}$ consumed/min/mg of protein) in okra cultivars Amarelinho and Mammoth Spineless stored at $5^{\circ} \mathrm{C}$, depending on time of immersion in water at $40^{\circ} \mathrm{C}$ [not immersed (A), 15 (B) and 30 (C) minutes immersed] and the sampling days $(0,4,8,12$ and 16 days). Means followed by the same letter in the column, for each combination of time of immersion in water at $40^{\circ} \mathrm{C}$ and day of sampling, do not differ at 5\% probability by the Tukey test. Viçosa, UFV, 2014.

defense of the fruits against oxidative stress contributing to the relief to CI in fruits stored under low temperature. This increase of CAT activity may be due to the decomposition of hydrogen peroxide, promoting the formation of water and oxygen, responsible for defense against oxidative stress, and alleviation of chilling injury (Shadmani et al., 2015).
Peroxidase activity in cultivar Amarelinho was lower for the longer immersion times in hot water, with maximum activity on the $6^{\text {th }}$ day of storage. Mammoth Spineless cultivar was not affected by treatment with average activity of $2.89 \mathrm{AU} / \mathrm{min} / \mathrm{mg}$ protein (data not shown).

The comparison between both cultivars showed that the average peroxidase activity on cultivar Amarelinho was higher (Figure 4). This fact would lead to believe that the peroxidase was most active in this cultivar because it is more susceptible to browning. However, visual analysis showed that the two cultivars behaved similarly with regard to darkening. Menolli et al. (2008) reported that the browning of arracacha roots coincided with the increase of peroxidase activity during storage at low temperatures.

In general, the concentrations of total phenolic compounds of the two cultivars were different, being higher in 'Mammoth Spineless'. Longer period of storage lead to greater concentration of phenolic compounds in fruits of this cultivar (Figure 5). The concentrations of total phenolic compounds in fruits of 'Amarelinho' were lower when preimmersed during 15 minutes in hot water fruits (Figure 5a).

Polyphenoloxidase activity of cultivar Amarelinho fitted in a quadratically model equation (Figure 6a). Evaluating the effect of immersion time in each sampling day, from the $4^{\text {th }}$ day of sampling, the fruits that were kept during 30 minutes in hot water had reduced polyphenoloxidase activity. And the activity was highest in fruits immersed during 10.4 minutes on the $8^{\text {th }}$ day of storage, with a value of $0.37 \mathrm{AU} /$ $\mathrm{min} / \mathrm{mg}$ of protein.(Figure $6 \mathrm{a}$ ).

The initial increase of enzyme activity could be related to low temperature stress of stored fruits and, it was verified that the onset of browning coincided with the increase in polyphenoloxidase (PPO) activity. However, hot water treatment has been used to inhibit polyphenoloxidase activity, since it reduces the rate of the polymerization step of browning reactions (Barbagallo et al., 2012). 
The decrease in enzyme activity may have contributed to the lower browning in the fruits. Heat-shock treatments have been shown to prevent browning reactions and maintain texture in various vegetables and fruits (Tsouvaltzis et al., 2011; López-López et al., 2013).

PPO of 'Mammoth Spineless'

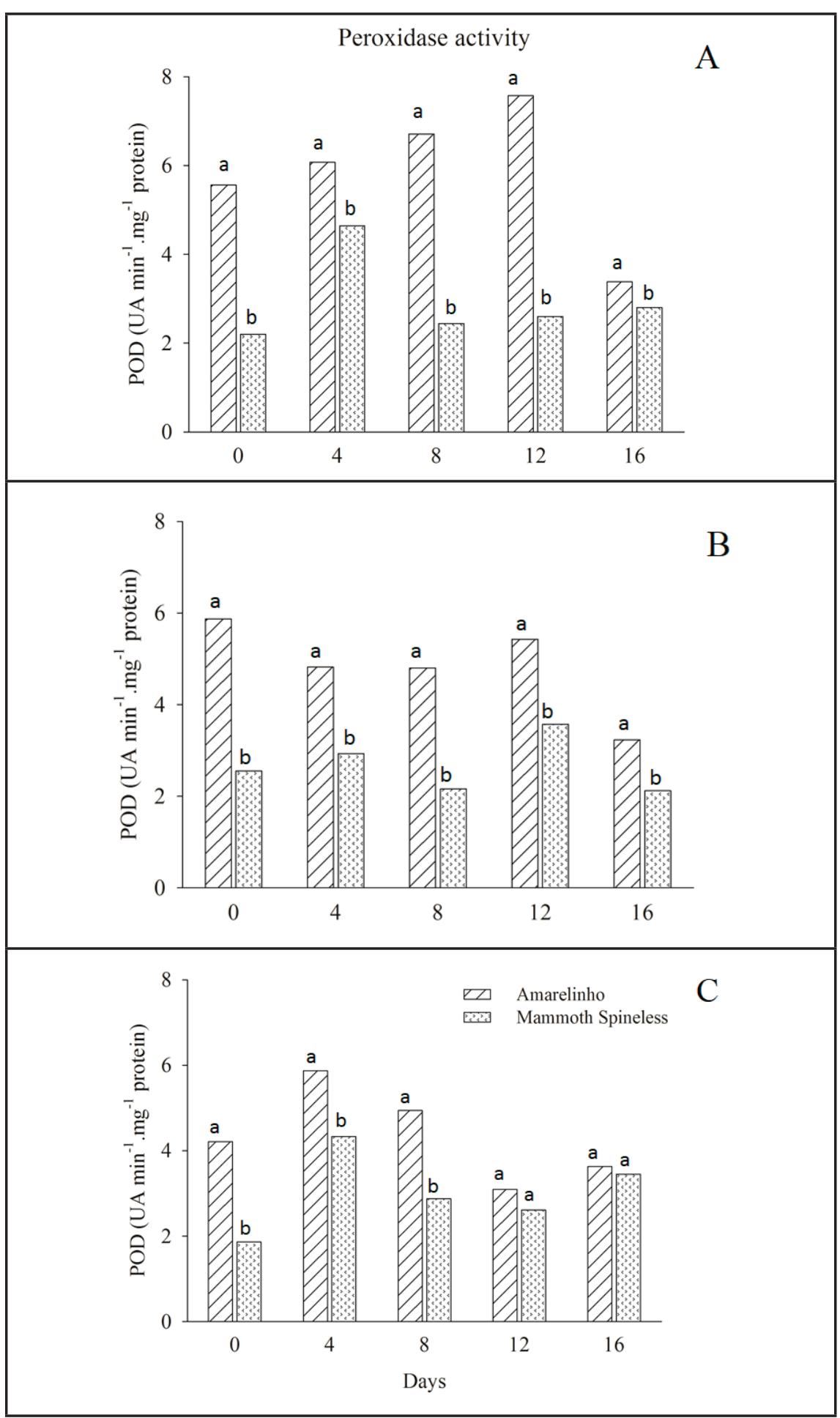

Figure 4. Mean values of peroxidase activity (POD) (UA/min $/ \mathrm{mg}$ of protein) in okra cultivars Amarelinho and Mammoth Spineless stored at $5^{\circ} \mathrm{C}$, depending on time of immersion in water at $40^{\circ} \mathrm{C}$ [not immersed (A), 15 (B) and 30 (C) minutes immersed] and the sampling days $(0,4,8,12$ and 16 days). Means followed by the same letter in the column, for each combination of time of immersion in water at $40^{\circ} \mathrm{C}$ and day of sampling, do not differ at $5 \%$ probability by the Tukey test. Viçosa, UFV, 2014. decreased linearly with increasing immersion time and showed quadratic behavior with the days of sampling (Figure 6b). The activity was maximum on the $7^{\text {th }}$ day of storage, control fruits (0.34 AU/min/mg of protein) showing greater activity in relation to treatment (0.29 AU/min/mg of protein).

The PPO activity was maximum on the $7^{\text {th }}$ day of storage for any period of immersion in water at $40^{\circ} \mathrm{C}$ during 30 minutes being the more efficient to reduce the enzyme activity (Figure 6b). The Amarelinho and Mammoth Spineless cultivars showed no differences in mean activity.

The comparison of the results with data on the visual analysis showed that the onset of browning of okra coincided with the increase of polyphenoloxidase activity. In the presence of atmospheric oxygen and PPO, monophenol is hydroxylated to o-diphenol and diphenol can be oxidized to o-quinones which then undergo polymerization to yield dark brown polymers (Chisari et al., 2007). In studies with arracacha roots (Menolli et al., 2008), loquats (Edagi et al., 2009) and processed kale leaves (Simões et al., 2015), a relationship was observed between browning and increased polyphenoloxidase activity, which also coincided with the increased content of phenolic compounds. In these studies, the stress caused to the fruits, due to the cold storage, may have turned on the secondary metabolism of the cells, which is one of the routes forming phenolic compounds (Ding et al., 2001), which explains the increase in the levels of total phenols. Nguyen et al. (2003) observed in a banana peel, the low temperature induced the activity of PPO, but with a decrease in phenolic compounds. This decrease correlated with the degree of browning may have been due to the use of phenolic compounds as a substrate for browning reaction.

The increase in polyphenoloxidase activity and the concentration of phenolic compounds coincided with increased darkening of okra. For peroxidase, this relationship is not observed. Considering the results, it is believed that browning in okra is mainly caused by non-enzymatic 


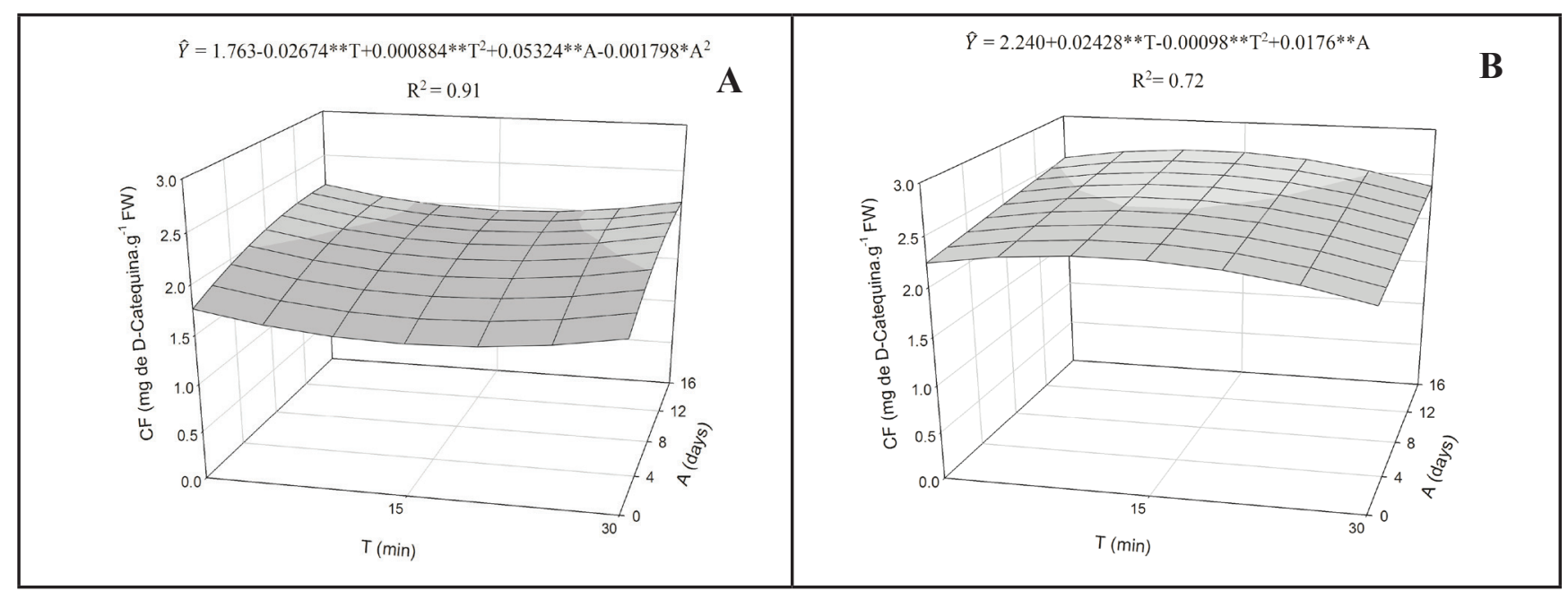

Figure 5. Estimation of concentration of phenolic compounds (CF) (mg of D-Catequina/g of FW) in okra cultivars Amarelinho (A) and Mammoth Spineless (B) stored at $5^{\circ} \mathrm{C}$, depending on time of immersion (T) in water at $40^{\circ} \mathrm{C}$ (not immersed, 15 and 30 minutes immersed) and the sampling days (A) (0, 4, 8, 12 and 16 days). Viçosa, UFV, 2014.

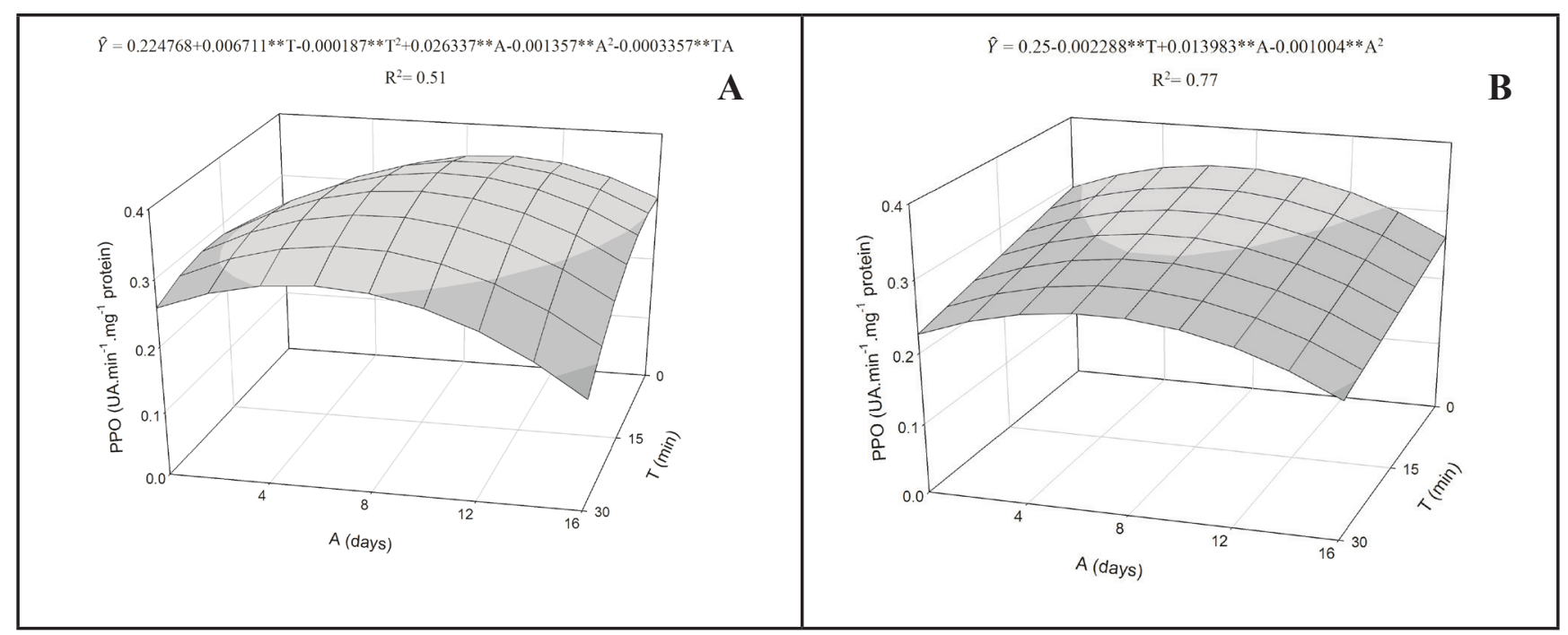

Figure 6. Estimation of polyphenoloxidase activity (PPO) (UA/min/mg of protein) in okra cultivars Amarelinho (A) and Mammoth Spineless (B) stored at $5^{\circ} \mathrm{C}$, depending on time of immersion (T) in water at $40^{\circ} \mathrm{C}$ (not immersed, 15 and 30 minutes immersed) and the sampling days (A) (0, 4, 8, 12 and 16 days). Viçosa, UFV, 2014.

reactions, triggered by the mixture of compounds due to cellular breakdown, caused by chilling injury. The Mammoth Spineless cultivar was more tolerant to chilling injury and had higher catalase activity, as well as higher levels of total chlorophyll and soluble phenolic compounds.

The heat treatment increased the length of storage days for both cultivars. The response of treated fruit to storage at lower temperatures with lower incidence of CI may be related to the antioxidant defense mechanism or to heat-shock treatment (Luengwilai et al., 2012). Recently, a comparative proteomic analysis in hot water treated citrus fruit was performed by Yun et al. (2013), revealed that resistance associated proteins were upregulated, but redox metabolism-related proteins were down-regulated by heat treatment. However, there is still a lack of molecular information about heat treatment especially the immediate responses of fruits (Wu et al., 2015).
The heat treatments during 15 and 30 minutes delayed at 4 and 6 days respectively the onset of symptoms of cold injury for the cultivar Mamoth Spineless. Moreover, according to the visual scale, the injury was lower in fruits of the cultivar Amarelinho immersed in hot water during 15 minutes. The darkening of the fruit immersed during 15 minutes was delayed for both cultivars, and the browning index was lower when compared to control treatment. The heat treatment during 15 
minutes increased the length of storage of cultivar Amarelinho, and during 30 minutes of the cultivar Mammoth Spineless.

\section{REFERENCES}

AGHDAM, MS, SEVILLANO, BL, FLORESC, FB, BODBODAKD, S. 2013. Heat shock proteins as biochemical markers for postharvest chilling stress in fruits and vegetables. Scientia Horticulturae 160: 54-64.

ARNON, DI. 1949. Copper enzyme in isolated chloroplasts polyphenoloxidase in Beta vulgaris. Plant Physiology 24: 1-15.

BARBAGALLO, RN; CHISARI, M; CAPUTA, G. 2012. Effects of calcium citrate and ascorbate as inhibitors of browning and softening in minimally processed 'Birgah' eggplants. Postharvest Biology and Technology 73: 107-114.

BRADFORD, MM. 1976. A rapid and sensitive method for the quantitation of microgram quantities of protein utilizing the principle of protein-dye binding. Analytical Chemistry 72: 248-254

CHISARI, M; BARBAGALLO, RN; SPAGNA, G. 2007. Characterization of polyphenoloxidase and peroxidase and influence on browning of cold stored strawberry fruit. Journal of Agricultural and Food Chemistry 55: 3469 3476.

CONCELLÓN, A; AŇÓN, MC; CHAVES, AR. 2004. Characterization and changes in polyphenoloxidase from eggplant fruit (Solanum melongena L.) during storage at low temperature. Food Chemistry 88: 17-24.

CORREIA, LG; FILHO, JAA; NAGAI, H. 1999. Quiabo. In: RIBEIRO, AC; GUIMARÃES, PTG; VENEGAS, VHA. (eds) Recomendações para o uso de corretivos e fertilizantes em Minas Gerais, $5^{a}$ Aproximação. Viçosa-MG, Comissão de Fertilidade do Solo do Estado de Minas Gerais. p. 202.

DING, CK; CHACHIN, K; UEDA, Y; IMAHORI, Y; WANG, CY. 2001. Metabolism of phenolic compounds during loquat fruit development. Journal of Agriculture and Food Chemistry 49: 2883-2888.

EDAGI, FK; SESTARI, I; SASAKI, FF; CABRAL, SM; MENEGHINI, J; KLUGE, RA. 2009. Aumento do potencial de armazenamento refrigerado de nêsperas 'Fukuhara' com o uso de tratamento térmico. Pesquisa Agropecuária Brasileira 44: 1270-1276.
FINGER, FL; DELLA JUSTINA, ME; CASALI, VWD; PUIATTI, M. 2008. Temperature and modified atmosphere affect the quality of okra. Scientia Agricola 65: 360-364.

KAR, M; MISHRA, D. 1976. Catalase, peroxidase, and polyphenoloxidase activities during rice leaf senescence. Plant Physiology 57: 315-319.

KUBOTA, N. 1995. Phenolic content and L-phenylalanine ammonia-lyase activity in peach fruit. In: LINSKENS, HF; JACKSON, JF (eds). Modern methods of plant analysis: Fruit Analysis. New York: Springer Verlag. p. 81-94.

LAGRIMINI, LM; GINGAS, V; FINGER, FL; ROTHSTEIN, S; LIU, TTY. 1997. Characterization of antisense transformed plants deficient in the tobacco anionic peroxidase. Plant Physiology 114: 1187-1196.

LÓPEZ-LÓPEZ, M; VEGA-ESPINOSA, A; AYÓN-REYNA, L; LÓPEZ-VALENZUELA, J; VEGAGARCÍA, M. 2013. Combined effect of hot water dipping treatment, Nacetylcysteine and calcium on quality retention and enzymatic activity of fresh-cut apple. Journal of Food Agriculture and Environment 11: 243-248.

LUENGWILAI, K; BECKLES, DM; SALTVEIT, ME. 2012. Chilling-injury of harvested tomato (Solanum lycopersicum L.) cv. Micro-Tom fruit is reduced by temperature pre-treatments. Postharvest Biology and Technology 63: 123-128.

MENOLLI, LN; FINGER, FL; PUIATTI, M; BARBOSA, JM; BARROS, RS. 2008. Atuação das enzimas oxidativas no escurecimento causado pela injuria por frio em raízes de batata baroa. Acta Science Agronomy 30: 57-63.

MOTA, WF; FINGER, FL; CASALI, VWD. 2000. Olericultura: melhoramento genético do quiabeiro. Viçosa: UFV. 144p.

MOTA, WF; FINGER, FL; CECON, PR; SILVA, DJH; CORRÊA, PC; FIRME, LP; MIZOBUTSI, GP. 2010. Conservação e qualidade pós-colheita de quiabo sob diferentes temperaturas e formas de armazenamento. Horticultura Brasileira 28: 12-18.

NGUYEN, TB; KETSA, S; VAN DOORN, WG. 2003. Relationship between browning and the activities of polyphenoloxidase and phenylalanine ammonia lyase in banana peel during low temperature storage. Postharvest Biology and Technology 30: 187-193.

PASQUARIELLO, MS; DI PATRE, D; MASTROBUONI, F; ZAMPELLA, L; SCORTICHINI, M; PETRICCIONE, M. 2015. Influence of postharvest chitosan treatment on enzymatic browning and antioxidant enzyme activity in sweet cherry fruit. Postharvest Biology and Technology. 109: 45-56.
SEVILLANO, L; SANCHEZ-BALLESTA, MT; ROMOJARO, F; FLORES, FB. 2009. Physiological, hormonal and molecular mechanisms regulating chilling injury in horticultural species. Postharvest technologies applied to reduce its impact. Journal of the Science of Food and Agriculture 89: 555-573.

SHADMANI, N; AHMADA, SH; SAARI, N; DINGA, P; TAJIDINA, NE. 2015. Chilling injury incidence and antioxidant enzyme activities of Carica papaya L. 'Frangi' as influenced by postharvest hot water treatment and storage temperature. Postharvest Biology and Technology 99: 114-119

SILVA, MV; ROSA, CILF; VILAS BOAS, EVB. 2009. Conceitos e métodos de controle do escurecimento enzimático no processamento mínimo de frutas e hortaliças. Boletim Centro de Pesquisa de Processamento de Alimentos 27: 83-96.

SIMOES, NA; MOREIRA, SI; MOSQUIM, PR; SOARES, NFF; PUSCHMANN, R. 2015. The effects of storage temperature on the quality and phenolic metabolism of whole and minimally processed kale leaves. Acta Scientiarum 37: 101-107.

TSOUVALTZIS, P; DELTSIDIS, A; BRECHT, JK. 2011. Hot water treatment and preprocessing storage reduce browning development in freshcut potato slices. HortScience 46: 1282-1286.

WANG, H; ZHANG, Z; XU, L; HUANG, X; PANG, X. 2012. The effect of delay between heat treatment and cold storage on alleviation of chilling injury in banana fruit. Journal of the Science of Food and Agriculture. 92: 2624-2629.

WU, Z; YUANA, X; LIA, H; LIUA, F; WANGA, Y; LIB, J; CAIC, H; WANGA, Y. 2015. Heat acclimation reduces postharvest loss of table grapes during cold storage - Analysis of possible mechanisms involved through a proteomic approach. Postharvest Biology and Technology. 105: 26-33.

YIMYONG, S; DATSENKA, TU; HANDA, AK. 2011. Hot water treatment delays ripeningassociated metabolic shift in 'Okrong' mango fruit during storage. Journal of the American Society for Horticultural Science 136: 441451.

YUN, Z; GAO, H; LIU, P; LIU, S; LUO, T; JIN, S; XU, Q; XU, J; CHENG, Y; DENG, X. 2013. Comparative proteomic and metabolomic profiling of citrus fruit with enhancement of disease resistance by postharvest heat treatment. Plant Biology 13: 44.

ZHANGA, N; YANGA, Z; CHENA, A; ZHAOA, S. 2014. Effects of intermittent heat treatment on sensory quality andantioxidant enzymes of cucumber. Scientia Horticulturae 170: 39-44. 